\title{
Organizational Transformation Solution through the Adoption and Implementation of Conceptual Model Designed to Achieve New Value Addition to Address Performance Shortfalls: A Survey from Green Valley Hyper Market Pakistan
}

\section{Mamoon Mustafa*}

Doctorate in Business Administration, University of Wales Trinity Saint David, United Kingdom

\begin{abstract}
This consultancy report was prepared as a strategic consultant for Green Valley Hyper Market to make a change through organizational transformation by using the performance gap analysis and to propose the implementation plan to implement the transformational change. The customers are not satisfied with the long queues and wasting lots of time for checkout. The company is losing its daily sale targets, as customers are frustrated to wait long for them to get to the cashier checkout. Using European Foundation for Quality Management excellence model key area were discussed to find the gap and make the proposal for the Green Valley Hyper Market to make their company position better in front of their competitors. The proposal has been made for the Green Valley Hyper Market to retain their existing customers and develop competitive advantages over other retailer in the market. The proposal implementation is totally based on transforming the current practice and give company gaining the strategic objectives they are looking for. The massive gap will be created with the valued customers, if they will not implement the transformational change that will shed away the company name and repute.
\end{abstract}

Keywords: Organizational transformation; Conceptual model

\section{Company Report Green Valley}

\section{Company introduction}

Green Valley is the project of Bahria Town Pakistan and the stores location are at the most favorite and prestigious place from the customer point of view and ideal for the people who want to have the best place to shop under one roof. The specialty of the Green Valley Hyper Market is the consultant who has made Waitrose and Spinneys has designed this stores with state of the art environment. The shoppers who have the experience of the western world feels comfortable to find almost all the international brands stuff and commodities. The great range of variety of products with the competitive price range and in comparison, it can easily overshadow the supermarkets and hyper stores with the unique and dynamic layout.

In Pakistan this is the first ever-big grocery store with the variety of product with biggest brand names and reasonable price. To be more customers centric the prices are changed on weekly basis to give price benefits to the customers to gain their loyalty towards the brand. The shelves offer the discounts with the price commitment promise.

The easy configuration on aisles makes customer easy and convenient to find the stuff with all the imported products and the different section in the Green Valley Hyper Market includes:

- Perfumes and cosmetic section

- Bakery section

- Toys section

- Home appliances section

- Juices and hot food corner

- Fishery and Butchery section

- Cutlery and crockery section.
The Green Valley Hyper Market environment is shopping as well as place for enjoyment with kids playing areas. This store brings life in the super stores category in Pakistan and gives strong feeling for the greater retail sector. Now they are in planning phase to cover every city of Pakistan with the advance structure for shopping.

\section{Terms of references}

Keeping in view the organizational transformation as a role of a consultant this report is prepared keeping the aspect of organizational transformation. The requirement of this consultancy reports achieved through following objectives.

1. Current status of the company to be identified through organizational transformation.

2. Making organizational proposal for the transformation by justifiable solutions.

3. The organizational transformation proposal to be implement by taking the top management into account with the help of leadership skills.

To achieve Green Valley Hyper Market objectives mentioned above for this consultancy report. Following structure were applied and engrossed.

*Corresponding author: Mamoon Mustafa, Doctorate in Business Administration, University of Wales Trinity Saint David, United Kingdom, Tel: 541-737-4411; E-mail: ursmamoon@hotmail.com

Received October 04, 2017; Accepted December 12, 2017; Published December 22, 2017

Citation: Mustafa M (2017) Organizational Transformation Solution through the Adoption and Implementation of Conceptual Model Designed to Achieve New Value Addition to Address Performance Shortfalls: A Survey from Green Valley Hyper Market Pakistan. J Bus Fin Aff 6: 307. doi: 10.4172/2167-0234.1000307

Copyright: (c) 2017 Mustafa M. This is an open-access article distributed under the terms of the Creative Commons Attribution License, which permits unrestricted use, distribution, and reproduction in any medium, provided the original author and source are credited. 
Citation: Mustafa M (2017) Organizational Transformation Solution through the Adoption and Implementation of Conceptual Model Designed to Achieve New Value Addition to Address Performance Shortfalls: A Survey from Green Valley Hyper Market Pakistan. J Bus Fin Aff 6: 307. doi: 10.4172/2167-0234.1000307

Page 2 of 8

1. Current situation analysis critically reviewed through gap analysis.

2. Company current shortfalls and expectations to be achieved through organizational transformation.

3. Proposal for the organizational transformation and implementing change.

4. Making best organization transformation structure for Green Valley Hyper Market.

5. Risk if company will not implement and accept the organizational transformation proposal (Table 1).

\section{Leaders with the people of organization reinforce a culture}

- Leaders of Green Valley should inspire people through their behaviors and actions and create a culture of involvement.

- Encourage transformation, organizational development and innovation and to generate new ideas promote culture that's supports their thinking.

\section{Leader ensure the change should be manage effectively}

- Through structured project management effectively manage transformation and change and focused improvement process

- Leaders for generating ideas should use structured approach.

Strategy based on capabilities and internal performance

- Customer's focus should be part of strategy and to achieve the strategic milestone identify development area of need.

- Based on the performance comparison establish targets and strategic goals.

\section{Organization's strategy supported by people, knowledge and} involvement

- To achieve the strategic goals clearly defined performance levels required for the people

- To maximize the contribution, ensure their people are competent.

- To grasp the potential of the people, align team and personal objectives.

- To improve the effectiveness of teamwork develops a culture through value chain.

\section{Partners, technology and information}

- For transformation, innovation and creativity to support culture use technology.

- Use collective knowledge and establish approach for generating innovation and ideas.

- Maximize the advantages through transforming the ideas into reality.

- To achieve mutual benefits, work together.

\section{Product and services}

- For the customers create value by innovative products and services.

- For the feedback do customer survey and market research for improvement in services and product.

- Change and transformation should be in line with existing customer potential group.

- In order to maximize customers value generation with relevant benchmark compare the performance.

- Continually monitor customer's experiences and make appropriate changes.

\section{Customers results}

- With the above action the company will see improvement in customers behaviors and attitude.

- Customers satisfaction.

\section{Business results}

- The performance indicators like financial and non-financial will be improve by this action.

\section{Literature Review}

\section{Organizational transformation}

Organizational transformation is a complex and challenging task for building the understanding for the radical change. The use of same words and terms in different way is confusing as used in literature of strategic change, academics and used by business consultants and executives. To clear the terminology difference, it is very important and must. The revolutionary and evolutionary two major change types does

\begin{tabular}{|l|l|l|l|}
\hline Strategic Objectives & Current Standing & GAP/deficiency \\
\hline $\begin{array}{l}\text { To listen and respond to the voice of the } \\
\text { customer and give more importance. }\end{array}$ & $\begin{array}{l}\text { In the retail sector to become customers } \\
\text { and consumers } 1^{\text {st }} \text { choice. }\end{array}$ & $\begin{array}{l}\text { Due to good customer base long boring } \\
\text { customer queues. }\end{array}$ & $\begin{array}{l}\text { In the growing technology era use } \\
\text { and enhance new technology and do } \\
\text { transformation. }\end{array}$ \\
\hline $\begin{array}{l}\text { To create the best supermarket with } \\
\text { all the products at best offering price } \\
\text { anywhere else. }\end{array}$ & $\begin{array}{l}\text { To offer the endless choice and highest } \\
\text { quality products for the customers at } \\
\text { reasonable price. }\end{array}$ & $\begin{array}{l}\text { Limited checkout tills with limited staff for } \\
\text { the assistance of the customers. }\end{array}$ \\
\hline $\begin{array}{l}\text { To focus and work hard with energy and } \\
\text { positive attitude and urgency. }\end{array}$ & $\begin{array}{l}\text { The internal décor is the world class } \\
\text { ambiance for the customer to shop. }\end{array}$ & No self-checkout tills. \\
\hline $\begin{array}{l}\text { For excellence in everything and to have } \\
\text { a passion of undying. }\end{array}$ & $\begin{array}{l}\text { The employees on the floor are very } \\
\text { efficient and cooperative unlike Asian } \\
\text { culture. }\end{array}$ & $\begin{array}{l}\text { The customers with less items has } \\
\text { to wait for long and that makes a big } \\
\text { congestion which cause delay in services } \\
\text { for other customers. }\end{array}$ \\
\hline $\begin{array}{l}\text { To make the customers happy to gain } \\
\text { good profit margin. }\end{array}$ & $\begin{array}{l}\text { Management is giving customer, } \\
\text { suppliers and employees full weightage. }\end{array}$ & $\begin{array}{l}\text { Customers are making worst comments } \\
\text { from services point of view on social } \\
\text { media making bad image and this way } \\
\text { sale is badly effecting. }\end{array}$ \\
\hline
\end{tabular}

Table 1: Company performance gap analysis. 
Citation: Mustafa M (2017) Organizational Transformation Solution through the Adoption and Implementation of Conceptual Model Designed to Achieve New Value Addition to Address Performance Shortfalls: A Survey from Green Valley Hyper Market Pakistan. J Bus Fin Aff 6: 307. doi: 10.4172/2167-0234.1000307

Page 3 of 8

differentiate by the literature. The radical and revolutionary types of changes are more often referred in transformational change [1-4]

Second-order planned change is also mentioned in transformation $[2,5]$. As the difficulties of an organization can easily be handled and plan for implementation and required change. In relation to the change in level of organizational transformation differences are there to be made and the impact on corporate level of the organization on the business and individual. The expected organizational transformation outcomes also include the last distinction. Improving the effectiveness of the organization by competitive advantages, survival of the organization and the gaining of the market share could include as the key drivers. The strategy of change must reflect the outcome if an organization wants to achieve the transformation is very important for its success.

The desires to move from of a business model and the existing state is driven by the organizational transformation where desired results are not achieved to a completely new improve business model and new state $[6,7]$. Each effort of radical change is focused by the vision or new state, i.e., and to reach the vision an effort is required for each change, which is planned and executed [8]. Failure of many change programs, are widely accepted [9-14] and the organizational effectiveness, would be enhanced by the effective change management. Many of them are made of better way to manage change $[15,16]$, including many arguments by the large body of work unless the organizational readiness is not there for the adoption of the change there is not point for the desired change [17]. The argument also contribute is this paper literature that in the complex situation where not only change is required in term of readiness but also the capacity of the organization which need change is also cater for.

\section{EFQM excellence model}

The European Foundation for Quality Management (EFQM) is the framework in the intensified global market and focus on the importance of quality through development awareness (Figure 1) [18]. Through deployment of process and to support organizational business and for continuous improvement. In the excellence performance the EFQM model important assumption is (e.g., people, customers, key performance and society) and five enablers derived these assumptions (e.g., people, strategy policy, leadership, resource, and processes). In different way this EFQM excellence model can be used. (1) As a selfassessment tool (2) With other organizations as a way of benchmark (3) Used as a guide to identify improvement area (4) Organization's management system structure [19]. As per author the EFQM is useful for every organization and for any problem area it's a best tool to find out the current situation and gives the solution for the future.

\section{Gap Analysis}

Revising the corporate objectives is the gap analysis first step. The upward revision of the objectives happens when the business expected outcomes exceeds the aspiration. The objectives can be revised downward if the business possible performance aspiration exceed [20]. With the help of this the author suggest that after finding the actual gap this will make the company strategic objective more clear and well define what exactly need transformation.

\section{Organizational transformation emergence}

The era when the business environments were stable than the incremental change occurred as noted by Dunphy and Stace [3]. The organizations major revolutionary changes described, and the program designed in 1980s and 1990s as emerged and described in literature. As Dunphy and Stace [3] describes under the business condition of widespread recession and economic restructuring organizational transformation arose on large scale. The arguments of some authors in the literature some says organizational development is due to extension of organizational transformation while the other says in its own rights the new discipline is represented by the organizational transformation.

\section{Transformation of industry}

To remain competitive, we have witnessed in the early 21 st century business environment in the industries were disruptive and rapid change of product and to speed up their cycle of strategy with the organizations under pressure [21]. Hofer [22] suggested that before an explicit investigation is carried out when a strategic turn around starts in the industry involved and its condition specially in particular its competitive structure and stage of evolution. At times when such strategic changes within an industry are abounds for such analysis reasoning are there.

\section{In an organization the role of learning}

In a strategic organizational transformation, the learning or learning an organization plays an important role as emphasized by many others [23]. The way of generating change and learning for an organization there is a need for new style and way of thinking as the concept of learning a company is confirmed by Tosey [24]. It is impossible according to the above authors, that without becoming a learning

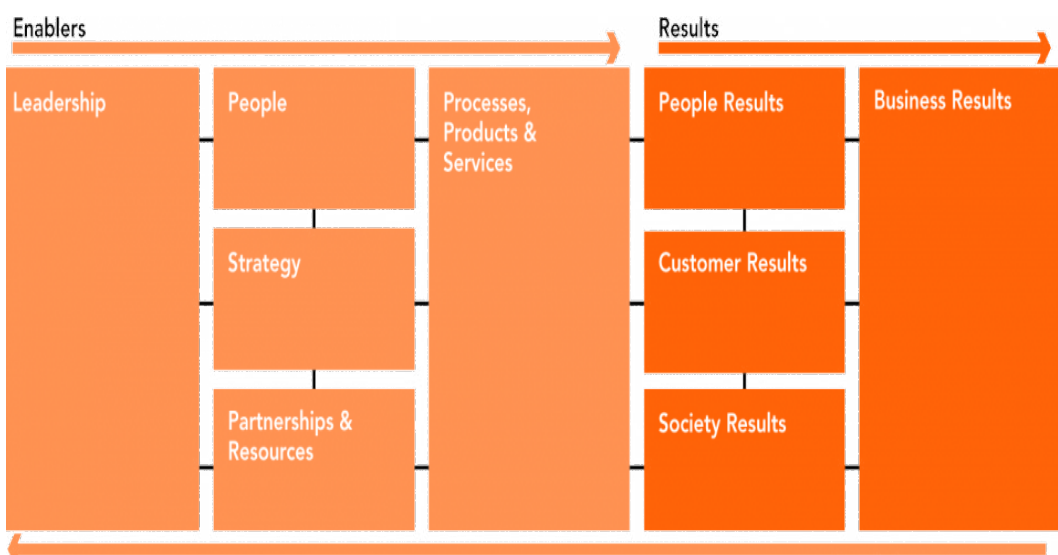

Figure 1: EFQM excellence model. 
Citation: Mustafa M (2017) Organizational Transformation Solution through the Adoption and Implementation of Conceptual Model Designed to Achieve New Value Addition to Address Performance Shortfalls: A Survey from Green Valley Hyper Market Pakistan. J Bus Fin Aff 6: 307. doi: 10.4172/2167-0234.1000307

Page 4 of 8

organization it is difficult to adapt successfully and continuously to the organization ever changing environment. For that the center of focus as strategic objective the knowledge management and innovation is must [23] furthermore, for the organization changing environment the survival of an organization the fundamental prerequisite is the ability of an organization to adapt and change which is the core of the learning [25] nevertheless, the change inspired learning and the rationale for learning is represented by the rapid change in the organizational environment and as a phenomenon one might agree to that can of change.

\section{Leadership role}

Beeby and Simpson [26] confirm that from the top manages the transformational change. The changing goals and clear picture must be known to the employees of the organization, which can only be affected when the organization clear vision and objective is shared, by the employee and the management. The author also described that from the cohesive and committed team, the higher-ups points out that work being facilitate by unified and visible leadership where the involvement of risk taking between the team members and the confirmation of climate of openness by Schneider and Goldwasser [27].

\section{Organization transformational leadership}

In an organization the managers experienced the contrast in leadership behavior and style as observed by De Wit and Meyer [28]. They also noted that very few great leaders are present and many of the organizations the head of the business unit and the CEO gets mere mortals and in a very human way they practice strategic change. This argument is supported by Tichy and Devanna [29] that the organizational change levers focused, by the consultants and the managers are very restricted and the limited practices of contemporary change management are observed [30]. Thus, they employ the same change levers regardless of the grave nature of the problem that they feel comfortable rather than the use of change levers with the success of business with highest probability.

\section{Organizational readiness}

In the recent years many organizations have implemented the change and magnitude whose importance has considerably increased [11,31]. To generate value and effectiveness and improvement of the organization such changes are targeted and taken into consideration $[32,33]$, the challenging environment can be handled by enabling a basic goal of an organization [16]. The organization change process is considered to be a continuous process rather than one state to another state movement, yet the rate of change initiatives is $70 \%$ of the failure and unsuccessfulness despite of change prevalence in the organization is widely accepted [9-14]

In different ways the term organizational change readiness is used $[34,35]$. The term refers to necessity of change initiatives and its successful implementation as referred by some authors whereas, other belief in the change benefits by the employees. Choi and Rouna [34] nevertheless, noted that common understandings on most of the definitions are agreed in relation to the organizational change readiness, and the individual evaluation is involved for making the successful changes and organizational capacity the organization gets the benefits from the need for change the members of the organization may also gain from this change.

\section{Customer satisfaction}

What the customer's experiences the failure or success is determine by the employee satisfaction [36]. Many research studies have confirmed that the relationship between the customer and employee satisfaction is the clear reciprocal $[37,38]$. This gives the suggestion that the employees are the internal customers of an organization, and through the employees' satisfaction performance the customers' needs will be able to meet.

The customers service and satisfaction effects by the employee satisfaction is identifies as following [36-39].

- In determining the quality of service, the important factor is the employee satisfaction.

- The continuous quality improvement process is committed by satisfied employees.

- For delivering the quality services they are more committed.

- The customers retention and satisfaction chances will be more by higher the degree of satisfaction of an employee. Furthermore, Vilares and Coelho [39], conducted a study in which they found that perceived satisfaction of employee, perceived loyalty of an employee and the impact of product and services quality is by perceived employee commitment and dedication

The several explanations, literature offers for why satisfaction of employees affects the satisfaction of the customers according to Bulgarella [40].

- To give respond to the needs and customers goal the employees develop more awareness and in a better position who interact with customers.

- Motivated employees are those whom are satisfied employee that is why to deliver care to customers they have motivational resources.

- Satisfied employee with resources and responsibility meets and understands customer's demands and needs in other words they are empowered employees.

- To render satisfactory services the energy level of satisfied employee is very high and the positive reflection is more obvious [36-43].

There is a suggestion that these interactional justice components in terms of interpersonal treatment and quality provided in exchange has more influence on customer's satisfaction. According to this point of view, satisfied employee delivers well as they experience interactional justice; in addition, to show empathy the satisfied employees have enough resources full of emotions, respect and other persons concern.

\section{Research Future Perspectives}

The need for the radical change gap has been identified based on the concept of transformation. Since the business practices in Pakistan are on the orthodox style and focusing generally on business development. A research gap has been identifies for the Green Valley Hyper market by doing organizational transformation and use of technology to make the company more progressive. The gap mentioned for the Green Valley Hyper Market with regards to Pakistan context the customers feel low-level satisfaction. As the company looks for bigger market share and become the blue ocean in their field. It is suggested that's to assist the new customers the expert supervisor from the maiden till evening should be positioned, at the self-checkout to avoid any delay cause by 
Citation: Mustafa M (2017) Organizational Transformation Solution through the Adoption and Implementation of Conceptual Model Designed to Achieve New Value Addition to Address Performance Shortfalls: A Survey from Green Valley Hyper Market Pakistan. J Bus Fin Aff 6: 307. doi: 10.4172/2167-0234.1000307

Page 5 of 8

new users. Time to time up gradation of the self-checkout system is necessary to avoid any errors and become more users friendly.

\section{Conceptual Framework of Transformation for Green Valley Hyper Market}

\section{Managing organizational transformation}

Green Valley Hyper Market will be confronted by this substantial change throughout the branches by implementing and introducing self-service check out system. The transition to desired state from the current state only occurs by organizational transformation. The transformation should be handled so technically that minimum resistance should be from the employees and transformation efforts should be maximize. Therefore, the process Green Valley Hyper Market will use to implement the self-check out system the objective of this consultancy report will revolve around that (Figure 2).

The push for transformation comes from top managers and employees at lower level which force the inside pressures to the company. And the technology change will be the outside pressure. For the Green valley Hyper Market brining the transformational change the internal factors play vital role.

To describe the difference between a performance of which it is capable and the company's actual performance the "performance gap" author uses this term. The resistance from the employees fails the change effort. The set of objective Green Valley Hyper Market should developed is customer satisfaction, increment in sale and cost effectiveness before implementing the transformational change.

\section{Areas of organizational transformation}

Three stages where Green Valley Hyper Market should make a strategic change:

1. When they realize for the company's situation, current strategy is no more suitable.

2. For the future directions and establish a vision.

3. Setting new system to support and implement the transformational change.

\section{Drivers of organizational transformation}

The major drivers for the Green Valley Hyper Market transformational change will be the new customers service and new technology implementation. The company may face new market and competitors by using this new service.

Additionally, by changing product or service the organization may face new competitors or new markets. The new change in the technology will change the working condition. The interaction of different forces will cause these changes and are classified as following:

\section{Internal drivers}

Internal drivers come from the organizational behavior analysis that's is why there is a need of technology adaption and changing the company strategy.

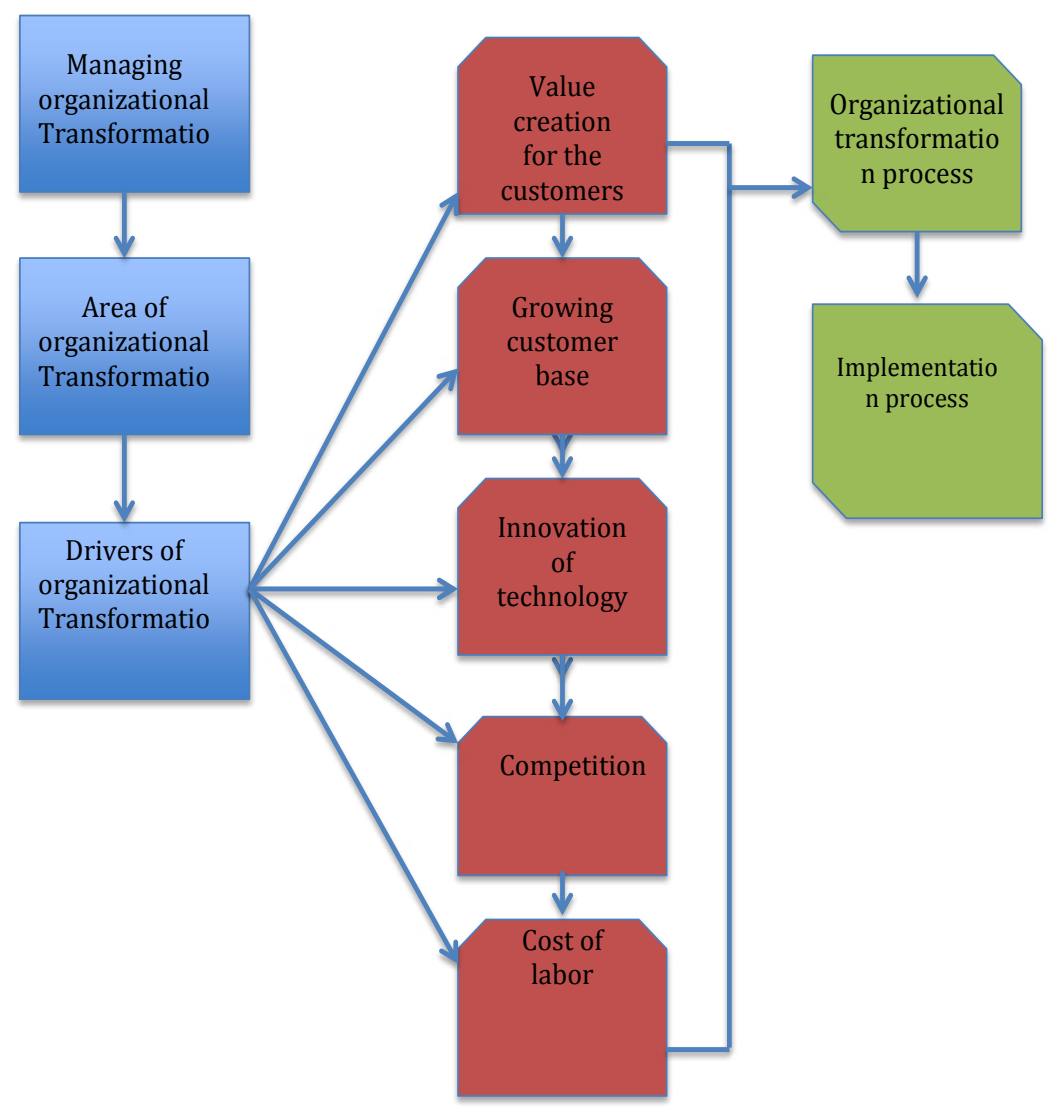

Figure 2: Conceptual framework of transformation for green valley hyper market. 
Citation: Mustafa M (2017) Organizational Transformation Solution through the Adoption and Implementation of Conceptual Model Designed to Achieve New Value Addition to Address Performance Shortfalls: A Survey from Green Valley Hyper Market Pakistan. J Bus Fin Aff 6: 307. doi: 10.4172/2167-0234.1000307

Page 6 of 8

\section{Drivers of transformation in green valley}

The drivers, which will trigger the transformational process, in the company will be discussed below:

Creation of value for customer: To retain the existing customers as part of Green Valley Hyper Market strategy, the company should focus on creating more customers value, by implementing the selfcheck out system to give customers better exciting experience.

Fast growing customer base: The fast growing customer base is the success factor for Green Valley Hyper Market. To ease the congestion on checkouts the self-checkout system should be implemented. With this new technology valued customers will not wait in long queues, either the customer only have purchased few items.

Innovations of technology: If the green Valley wants to be successful in this technology growing age the company has to make the operational efficiency effective by implementing self-checkout.

Competition: Green Valley Hyper Market will get the competitive advantage over its competitors after implementing self-checkout system. This will make the difference with other retailers in the market.

Cost of labour: To maximize the profits is every business aim. Green Valley Hyper Market by using the self-checkout system will safe time and cost. For instance, for four self-checkout systems only one cashier will be required to assist the customer.

\section{Proposed Plan for Organizational Transformation of Green Valley Hyper Market}

\section{The process of organizational transformation}

For every transformational change action plan is required to give the clear picture how the change will require and will effect the organization. The basic structure for Green Valley Hyper Market will be as under:

1. To achieve the organizational goals, the course of action should be identified.

2. Authority to be designated who will drive the organizational change.

3. Identify role of individuals who will led the change process.

4. Identify the training required to enable people for the change process.

The top level of management will initiate and implement the organizational change. The top level will define and develop the solution for the problems. Once the decision will be made for the change, communicate the people who will be involve is this process. The change from the top level is the common misconception amongst the organizations. The involving people are the foundation of affected change. Top and lower levels will be jointly responsible for developing and identifying the problem and shares the responsibility of transformation. The shared responsibility will be addressed in several ways as given below:

1. To develop and gathered the information to define the problem top management should use staff groups for the solution. And in order to obtain the reaction communicate the identified solution to the lower staff groups. To modify the solution lower staff feedback will be used for the solution.

2. To develop the solution task force should be appointed by the top management to seek lower level involvement and define the problem. The final decision will be made after the recommendation provide by task force. The people part of the task force will be those who will be directly affected and have the expertise of the area of proposed change. By this involvement the group commitment to the transformation may be made deeper and more focused.

3. To develop the solution after collecting the information about the problem from all levels the composition of task force should be formed. In this approach the underlying assumption will be to develop the quality solution the people at top, middle and bottom level will be needed and at the same levels commitment must be build. This integration of transformation into work place will be the organizational success at all levels.

\section{Transformational management objectives - green valley hyper market}

To measure the organizational effectiveness before implementing the technological change Green Valley Hyper Market should devised the following developed objectives:

- A radical change in customer satisfaction.

- Cost effectiveness will be achieved.

- A substantial increase in overall sales.

\section{The implementation process of transformation}

In Green Valley Hyper Market, the self-checkout systems implementation is said to a strategic change. The way transaction process carried out the new self-checkout systems will be different from the normal checkout. The self-checkout systems do not require cashier whereas, the cashier checkout required a proper cashier to operate. The new procedure introduced, as self-checkout systems will serve customers in a different method. Without taking much of times in long queues this self-checkout system will give customers enhanced service for saving time. The self-checkout systems introduced in Green Valley Hyper Market will improve the valued customers shopping experience, and make them shop very comfortably. This will make the customer feel part of Green Valley Hyper Market. The customers after purchasing the items they want to buy from the shelves will go to selfcheckout systems, and pay for the items purchased. The effect of this proposed system will be the synergy of both cashier checkout and selfcheckout.

\section{Resistance to Transformational Change}

The human nature is always reactive in implementing the change and it's a critical factor for the transformational change for implementation. Sometime, the strict transformation structured ignores the ingrained transformational change human resistance. The people who will be affected by this transformational change will be spending more time in wasting energies in figuring out the alternative for the change where they can easily survive. Sometimes, this reaction of change is overlook or forgets by the managers. The organizational transformation effective strategies involve human being behavior understanding in the work force.

\section{Resistance management at green valley hyper market}

If Green Valley Hyper Market wants to be successful in its activities in any organization effective planning is imperative. The main task for the top management of the Green Valley Hyper Market is to figure out 
Citation: Mustafa M (2017) Organizational Transformation Solution through the Adoption and Implementation of Conceptual Model Designed to Achieve New Value Addition to Address Performance Shortfalls: A Survey from Green Valley Hyper Market Pakistan. J Bus Fin Aff 6: 307. doi: 10.4172/2167-0234.1000307

Page 7 of 8

in which stores they will first introduce the self-checkout system. As the new system has the demo function and its user friendly for the new user, how to operate, but still the management at Green Valley Hyper Market has to train the person who will be assisting the customers for using the new self-checkout systems. Due to human nature the will, be feeling insecure for losing their job because of this self-checkout system. It's the prime obligation of the Green Valley management to make the cashier understand the purpose of this new technology and the potential benefit it will give to the organization and customers as a whole. With the front-end leaders, the assistance will be provide assistance to customers and encourage them to use this self-checkout system. The management should get the feedback from the staff and the customers how they feel while using this service and this will help the management to take the decision to install the self-checkout system on the other Green Valley Hyper Market outlets.

\section{In meeting green valley objectives extent to which transformation will be successful}

This transformational change process will have the immense effect by implementing the self-checkout system on to the entire organization will have positive impact on the customer experience and sale of Green Valley Hyper Market. The self-checkout system major benefit to company will be as following.

Increase in revenue and sales: In this modern era of marketing where different tools can be use to help the system the major focus of almost every company is the customers, and they will only prefer to go where they will feel convenient to shop and save the time. This new technology will attract the new costumers, and this self-checkout system will help them to leave the store well in time.

Cost effectiveness: This new technology will help to reduce the cost of the labor as this self-checkout system will be self-operated and the need of staff will be very less as compared to the cashier's check out. However, in case of any malfunctioning a trained supervisor staff will be required to assist the value customers.

Customer satisfaction: This new self-checkout system will give good and speedy service to the prestigious customers, and the use of this technology, will improve the satisfaction level customers aspect. The good relationship with the customers will be formed with this new technology and will result in customer loyalty, which is the main motive and vision of any business.

\section{Risk to green valley hyper market for not implementing the transformation}

Following risk will be faced by the company if not implementing the transformational change:

1. The company will lose the market share if the customer satisfaction factor will be not taken into account.

2. The sale of the company will be decrease as the customers wants to avoid the long queuing and safe the time.

3. The customer loyalty will be badly affected.

4. If the company will not implement this transformation they will not reach their strategic objectives and future goals.

\section{Conclusion}

The technology has advantages as well as disadvantages, which should always be cater for as this new self-checkout will be well appreciated by the customers and the retailers likewise there are some challenges they will came across. The purchase of loose vegetables and fruit items without barcode will confuse the customer and make them frustrated if the customer doesn't have much IT knowledge. After scanning the products if customer will not place the item in the baggage area they will need assistance of the supervisor standing there that will sometimes make the customer irritated. As a whole this new technology transformation will boost the sale and make the customers feel good while purchasing the items and will definitely safe the precious time in not standing in long queues.

\section{References}

1. Miller D, Friesen P (1982) Structural Change and Performance: Quantum Versus Piecemeal-Incremental Approaches. Academy of Management Journal 25: 867-892.

2. Levy A (1986) Second-order planned change: Definition and conceptualization Organizational Dynamics 15: 5-23.

3. Dunphy DC, Stace DA (1988) Transformational and Coercive Strategies for Planned Organizational Change: Beyond the O.D. Model. Organization Studies 9: 317-334.

4. Dunphy D, Stace D (1992) Under new management, Australian organizations in transition (1st edn.), Sydney: McGraw-Hill.

5. Bartunek JM, Louis ML (1988) The interplay of organizational development and organizational transformation Research in Organizational Change and Development 2: 97-134.

6. Kilmann RH, Covin TJ, Katz JM (1988) Corporate Transformation: Revitalizing Organizations for a Competitive World: Jossey-Bass Publishers.

7. Francis D, Bessant J, Hobday M (2003) Managing radical organizational transformation. Management Decision 41: 18-31.

8. Miles R (1997) Leading corporate transformation. (1st edn.), San Francisco: Jossey-Bass.

9. Attaran $M(2000)$ Why does reengineering fail? A practical guide for successfu implementation. Journal of Management Development 19: 794-801.

10. Beer M, Nohria N (2000) Cracking the Code of Change. Harvard Business Review 78: 133-141.

11. Grady VM, Grady JD (2012) The Relationship of Bowlby's Attachment Theory to the Persistent Failure of Organizational Change Initiatives. Journal of Change Management 13: 206-222.

12. Self DR, Schraeder M (2009) Enhancing the Success of Organizational Change: Matching Readiness Strategies with Sources of Resistance. Leadership and Organizational Development Journal 30: 167-82.

13. Weiner BJ (2009) A Theory of Organizational Readiness for Change. Implementation Science 4: 67.

14. Werkman RA (2009) Understanding failure to change: A pluralistic approach and five patterns. Leadership \& Organization Development Journal 30: 664-684.

15. Kanter RM (1989) When giants learn to dance. (1st edn.), Simon and Schuster New York

16. Kotter J (1996) Leading change. (1st edn.), Mass: Harvard Business Schoo Press, Boston.

17. Armenakis AA, Harris SG (2002) Crafting a change message to create transformational readiness. Journal of Organizational Change Management 15: 169-183.

18. Evans JR, Lindsay WM (2005) The management and control of quality. US, South-Western, Thomson.

19. EFQM (2016) The EFQM Excellence Model

20. Channon D, Sammut-Bonnici T (2015) Gap Analysis. Wiley Encyclopedia of Management, pp: 1-2.

21. Hamel G (2000) Leading the revolution. (1st edn.), Mass.: Harvard Business School Press, Boston.

22. Hofer CW (1980) Turnaround Strategies. Journal of Business Strategy 1: 19-31. 
Citation: Mustafa M (2017) Organizational Transformation Solution through the Adoption and Implementation of Conceptual Model Designed to Achieve New Value Addition to Address Performance Shortfalls: A Survey from Green Valley Hyper Market Pakistan. J Bus Fin Aff 6: 307. doi: 10.4172/2167-0234.1000307

Page 8 of 8

23. Espejo R, Schumann W, Schwaniger M, Bilello U (1997) Organizational transformation and learning. Chichester: Wiley

24. Tosey $P$ (1994) Energies of organization and change. (1st edn.), Berkshire: McGraw-Hill.

25. Grieves J (2000) Navigating change into the new millennium: themes and issues for the learning organization. Learning Organization 7: 54-74.

26. Beeby M, Simpson $P$ (1995) Developing strategic processes for change in top management teams. Executive Development 8: 20-22.

27. Schneider D, Goldwasser C (1998) Be a model leader for change. Management Review 87: 41-46.

28. De Wit B, Meyer R (2004) Strategy: Process, Content, Context. (3rd edn.), Thomson Learning, London, UK.

29. Tichy N, Devanna M (1986) The Transformational Leadership. John Wiley \& Sons, New York.

30. Kumar MR (2005) Total quality management as the basis for organizationa transformation of Indian Railways: A study in action research. Southern Cross University, ePublications, pp: 1-393.

31. Burns B, Jackson P (2011) Success and Failure in Organizational Change: An Exploration of the Role of Values. Journal of Change Management 11: 133-162.

32. Cawsey T, Deszca G, Ingols C (2012) Organizational Change: An ActionOriented Toolkit. Thousand Oaks: Sage Publications Ltd.

33. Hayes J (2002) The Theory and Practice of Change Management. Palgrave New York.
34. Choi M, Ruona W (2011) Individual Readiness for Organizational Change and Its Implications for Human Resource and Organization Development. Human Resource Development Review 10: 46-73.

35. Weiner B, Amick H, Lee Shoou-Yih D (2008) Conceptualization and Measurement of Organizational Readiness for Change: A Review of the Literature in Health Services Research and Other Fields. Med Care Res Rev 65: 379-436.

36. Ledimo O (2016) An Evaluation of the Role of Leadership on Employees' Job Satisfaction. Corporate Ownership and Control 14: 466-475.

37. Comm C, Mathaisel D (2000) Assessing employee satisfaction in service firms: An example in high education. The Journal of Business and Economic Studies, Fairfield, pp: 43-53.

38. Voisard V (2008) Employee empowerment and employee satisfaction in the workplace. California Sociology Journal 1: 1-17.

39. Vilares MJ, Coelho PS (2000) The employee-customer satisfaction chain in the ECSI model. European Journal of Marketing 37: 1703-1722.

40. Bulgarella CC (2005) Employee satisfaction and customer satisfaction: Is there a relationship? Guidestar Research White Paper, pp: 1-6.

41. Blackman D, O’Flynn J, Ugyel L (2013) A Diagnostic Tool for Assessing Organizational Readiness for Complex Change. Academy of Management conference, The Australia and New Zealand School of Government.

42. Burgoyne J, Pedler M, Boydell T (1994) Towards the learning company. (1st edn), McGraw-Hill, London.

43. Greenvalley (2016) Mission Statement. 